\title{
IMPROVING VOCABULARY THROUGH AFFIXES AT SECONDARY LEVEL
}

\author{
Muhammad Safdar Bhatti ${ }^{1}$, Asif Iqbal ${ }^{2}$, Zahida Javed ${ }^{3}$ \\ ${ }^{1}$ TEFL Coordinator, AIOU Bahawalpur, Pakistan, safdarbhatti2001@gmail.com \\ ${ }^{2}$ Assistant Professor Dr., Education, GC University Faisalabad, asifphd@hotmail.com \\ ${ }^{3}$ Lecturer Education, GC University Faisalabad, zahidajaved@outlook.com
}

\begin{abstract}
English is being used all over the world as an international language. It has become a Lingua Franca and a language of greater opportunities. It also enjoys a supreme status in society. Its sound knowledge is a successful passport for any job. For learning any language, both the oral and written skills are of equal importance. In fact, learning a second language is never easy. Learners have to wrestle with new vocabulary, rules of grammar, pronunciation and more. In learning a second language, vocabulary is the most paramount part. It is the soul and essence of a language. It is also first and leading stair in a language acquisition. Its knowledge plays an important role in almost all areas of language. So, the whole process of learning a language depends on learning its vocabulary. The current study evaluates the ways to improve vocabulary through affixes at secondary level. It was an experimental type of research. Three hundred and sixty students (180 males and 180 females) from two Govt. High schools in district Bahawalpur participated in this study. Experimental research with pretest posttest design was used. The data were collected through tests. The findings of the study revealed a significant improvement in vocabulary using affixes. It is recommended that quizzes, exercises and tests for affixes should be used to enhance the vocabulary among students. The conclusion with suggestions was also summed up at the end of the study.
\end{abstract}

Keywords: Evaluates, Improve, Affixes, Vocabulary, ESL learners, Stratified

\section{INTRODUCTION AND REVIEW OF RELATED LITERATURE}

The study of prefixes roots and suffixes is the most utilized word parts that make fifty percent of the English language (Pitman, 2003). English vocabulary is marvelous and becomes the part and parcel of technology and social interaction. New words presented, and an incredible rate of the words used to express extract thoughts, are perplexing words that comprised of basic word parts (prefixes, roots, and postfixes). They have their own particular definitions and when familiar to students, comprehend without a precise definition. Gradual practice of prefixes roots and suffixes can improve vocabulary among students (Pitman, 2003).

Mastering or practicing the four skills of English language teaching are objectiveless if they have not a few words made up of prefixes, roots and suffixes. It is the beginning of learning a language (Pitman, 2003). English language has become a key to interaction among global community. Today the It is spoken and understood almost everywhere in the world. All the administrative issues regarding business, political and academic are discussed in English. In Pakistan, English is being used and understood as second language. It is an essential part from KG to university level. Unfortunately in Pakistan; English is considered a difficult language due to 
different structure of vocabulary and pronunciation from local languages. According to Schmitt (2000) the knowledge of words related to its meaning and clarifications is called vocabulary. Vocabulary learning is the fundamental element in mastering a second language. Vocabulary learning is a confused process. They are vocabulary acquisition, vocabulary retention, and vocabulary transfer (Schneider et al., 2002).

Lado (1955) reported three aspects (semantics, syntax, and arrangement of words) are focused during vocabulary teaching. Different languages have different sentence structures, meanings and arrangement of words which lead to multiple vocabulary learning issues. There are social, psychological, and neurological factors involved in learning and retaining of vocabulary. A child is socialized under the influence of parents, school and peers. They play vital role in learner's literary events. Pinta, (2004) states that interaction between adults and a child is the primary source of child's education.

According to Stoller and Grabe (1993), the development of vocabulary is necessary for both native and nonnative learners. Kaivanpanah and Zandi (2009) explore that first and second language cannot be comprehended without vocabulary knowledge. Hulatijn (2005) believed, "if one does not know the meaning of the words occurring in a text, understanding is severely hampered" (p.54). Quin and Irvings (1997) analyzed, "the hardest way to learn new words is a try to memorize a list of unrelated words and their meanings". According to Wei (2007), long term retention is one of the greatest problems in learning new vocabulary.

The issues of vocabulary learning strategies were studied by different experts. According to Paivo (1986), the basic unit of success in the second language classroom is vocabulary. It has an important role in the success of second language learners. Vocabulary is one of the major complaints of learners. They are unable to retain the vocabulary items for a long period. Current studies are not sufficient to solve this issue. The learners forget vocabulary words. Students learna large number of words but they cannot retain those words in their long term memories. Consequently, this study is expected to help learners in learning and retaining vocabulary through affixes

In a language, words are building blocks. Learners begin to develop knowledge of second language by learning the words. In a language, words do not exist as isolated items. Words are interwoven in a system in order to achieve understanding in reading or listening or produce ideas in writing and speaking. Richard (1976) stated that word association; register and semantic structure are included in lexical items.

Oxford and Scarcella (1994) has presented different approaches regarding the teaching of vocabulary which is based on relevant research related to learner's motivation and need, difficulty to know a word and the factors which influence the acquisition of L2 vocabulary. In a traditional approach, usually the vocabulary is taught in the class unsystematically and the teachers make their learners to learn the vocabulary at their own cost without the guidance and instructions from the teachers. Whereas in this new research based approach the learners are made to learn vocabulary systematically, focusing the words which students are supposed to come across frequently. Nation (2001) stated that vocabulary learning strategies are a part of general learning strategies. According to Nation, there are three general classes of vocabulary learning strategies.

\section{WORD MEANING THEORY}

There exists a basic structure behind every word, fixed meaning and fuzzy meaning. In fixed meaning the learners acquire the core meaning of a word, the fuzzy meaning is not concerned with fixed meaning (Aitchison, 2003). They are constructed into planning that choose (words, different aspects of knowledge strategies), sources of getting information the words (learning form word card, context, dictionary and parallels), and Process (of noticing, retrieving and generating).

\section{TECHNIQUES OF VOCABULARY RETENTION (TVRS)}

Oxford (1990) suggested some memory strategies which help the learners in storing and recovering new information.

\section{GROUPING ASSOCIATION}

Grouping is a way to classify language materials into meaningful units. It is an easy way to remember new words. We make different group of words in this way. For example, kind of word (verbs, nouns), semantic (statement) or theme (words about weather). New words are associated to old memory concepts for example, "erroneous "means mistaken, the students might associate it with the word "error".

\section{WORDS CONTEXT TECHNIQUE}

New words can be placed in long-term memory by using them meaningful sentences, dialogues or in a story. 


\section{USING IMAGERY}

New language information can be stored in memory by means of meaningful imagery.

\section{SEMANTIC MAPPING}

Related words are arranged by means of arrows and lines in semantic mapping.

\section{VISUAL AND AUDITORY LEARNING}

Repeating new words is a technique in which words are pronounced loudly. Words are used in sentences to increase the retention skill. By reading newspapers and magazine etc. students can learn new words. It will help the students to learn about sentence structure and pattern. New information can be learnt in practice and context in order to improve retention rate. Flashcards can be used to develop interest among students. In this technique words are written on flashcards with pronunciation on one side, and definition on the other side. In recycling, students learn words by different exercises in different duration. Matching, fill in the blanks; prefix and suffix are included in these exercises.

\section{OBJECTIVES OF THE STUDY}

The objectives of the study were:

1.to compare the achievement score of secondary school students

2. to analyze the effective role of Affixes and Prefixes in improving vocabulary.

3.to analyze effective vocabulary learning strategies between male and female learners.

\section{RESEARCH QUESTIONS}

To achieve the required objectives, following research questions were formulated:

RQ1: Is there exist any significant difference between the achievement score of overall pretest and posttest?

RQ2: Is there exist any significant difference between the achievement score of male group pretest and posttest?

Ho3: Is there exist any significant difference between the achievement score of female group pretest and posttest?

\section{RESEARCH DESIGN}

This research is experimental in nature which includes both groups experimental and control group.

\section{POPULATION}

Secondary level learners of Bahawalpur City were the part of the study. The data for this study were collected from the secondary level students in the academic year 2015. The study was limited to the Bahawalpur City only.

\section{SAMPLING AND PROCEDURE}

In this study, three hundred and sixty students of two Govt. High Schools in Bahawalpur participated in this research. They were further subdivided in 180 males and 180 females. Ninety students were selected in experimental group and same number $\mathrm{n}$ control group. The experiment lasted for four weeks (36 hours in total, two hours daily class). They learnt the most prevalent prefixes and suffixes (ad-, un, less, ness, de-, ex-, in-, and -tion, -ate, -al, anti) due to continue repetition and practice.

\section{DATA COLLECTION}

Test was used to collect data to find out the vocabulary improvement level of the students. According to this classification, strategies are classified in Affixes. The test items were selected on the basis of Affixes and Prefixes developed by Gruber (1986). Questionnaire was delivered to students to evaluate their performance.

\section{DATA ANALYSIS}

RQ1: Is there exist any significant difference between the achievement score of overall pretest and posttest? 
Table 1

Comparison between Overall Pretest Posttest Results

\begin{tabular}{|c|c|c|c|c|c|}
\hline Tests & Mean & $\mathrm{N}$ & Std. D. & t-value & sig \\
\hline \multirow{2}{*}{$\begin{array}{c}\text { Pretest } \\
\text { Posttest }\end{array}$} & 64.04 & 360 & 10.93 & \multirow{2}{*}{-6.258} & \multirow{2}{*}{$.000^{\star *}$} \\
\cline { 2 - 5 } & 68.21 & 360 & 8.64 & & \\
\hline
\end{tabular}

${ }^{* *} p<0.01$

According to table 1, a significant difference found in students' achievement scoreof pretest posttest results. The mean achievement score of pretest participants $(M=64.04, s d=10.93)$ and posttest participants $(M=68.21$, $s d=8.64)$ with ( $p$ value $<0.05$ ) shows that posttest group students had performed better than that of pretest group. So the research question that, "Is there exist any significant difference between the achievement score of overall pretest and posttest?" answered in positive. It revealed that affixes practice has positive impact in enhancing the vocabulary of students.

RQ2: Is there exist any significant difference between the achievement score of male group pretest and posttest?

Table 2

Comparison between Male Group Pretest Posttest Results

\begin{tabular}{|c|c|c|c|c|c|}
\hline Tests & Mean & $\mathrm{N}$ & Std. D. & t-value & sig \\
\hline \multirow{2}{*}{$\begin{array}{c}\text { Pretest } \\
\text { Posttest }\end{array}$} & 64.26 & 180 & 10.61 & \multirow{2}{*}{-3.793} & \multirow{2}{*}{$.000^{* *}$} \\
\cline { 2 - 4 } & 67.99 & 180 & 10.16 & & \\
\hline
\end{tabular}

${ }^{* *} \mathrm{p}<0.01$

The table 2depicted a significant difference in students' achievement score of pretest posttest results in male group. The mean achievement score of pretest participants $(M=64.26, s d=10.61)$ and posttest participants $(M=67.99, s d=10.16)$ with ( $p$ value $<0.05)$ shows that posttest group students had performed better than that of pretest group. So the research question that, "Is there exist any significant difference between the achievement score of male group pretest and posttest?" answered in positive. It revealed that affixes practice has positive impact in enhancing the vocabulary of students in male group.

Ho3: Is there exist any significant difference between the achievement score of female group pretest and posttest?

Table 3

Comparison between Female Group Pretest Posttest Results

\begin{tabular}{|l|c|c|c|l|l|}
\hline Tests & Mean & $\mathrm{N}$ & Std. D. & t-value & sig \\
\hline Pretest & 63.82 & 180 & 11.27 & & \multirow{2}{*}{ Posttest } \\
\cline { 2 - 6 } & 68.43 & 180 & 6.81 & & $.000^{* *}$ \\
\hline
\end{tabular}

${ }^{* *} \mathrm{p}<0.01$

The table 3showed a significant difference in students' achievement score of pretest posttest results in female group. The mean achievement score of pretest participants $(M=63.82, s d=11.27)$ and posttest participants $(\mathrm{M}=68.43, \mathrm{sd}=6.81)$ with $(\mathrm{p}$ value $<0.05)$ shows that posttest group students had performed better than that of pretest group. So the research question that, "Is there exist any significant difference between the achievement score of female group pretest and posttest?" answered in positive. It revealed that affixes practice has positive impact in enhancing the vocabulary of students in female group. 


\section{RESULTS AND DISCUSSION}

A significant difference was found in students' achievement score of pretest posttest results. The posttest group students had performed better than that of pretest group. It revealed that affixes practice has positive impact in enhancing the vocabulary of students.

The students' achievement score of pretest posttest results in male group differ significantly. The posttest group students had performed better than that of pretest group. It revealed that affixes practice has positive impact in enhancing the vocabulary of students in male group.

A significant difference was explored in students' achievement score of pretest posttest results in female group. The posttest group students had performed better than that of pretest group. It exposed that affixes practice has positive impact in enhancing the vocabulary of students in female group.

\section{CONCLUSIONS}

In four weeks (36 hours) the students were able to recognize complex words in their own. They can break the words in their parts. Those students are rewarded who use complex words in their writing or speaking. They learnt the most prevalent prefixes and suffixes (ad-, un, less, ness, de-, ex-, in-, and -tion, -ate, -al, anti) due to continue repetition and practice. At first, they felt it difficult and hesitant but over time they naturally became more confident, and learnt how to teach themselves the language. The confidence of students was assessed by quiz scores. When the students were presented a list of words, they surprised to see many words they handled. The teacher's reward was to judge the learners to apply the learnt words in their everyday lives. Building the vocabulary and its comprehension is the utmost aspect of learning a language.

\section{RECOMMENDATIONS}

As English is not a native language in Pakistan. The only way to overcome the difficulty to master four skills is to practice the language so that the desired level may be achieved. For this purpose the teachers must be trained and the students should be encouraged to improve the vocabulary level through continuous improvement and guidance at school.

\section{REFERENCE LIST}

Aitchison, J. (2003). Words in the mind. Blackwell Publishing Ltd.

Chen, W. W. (2003). Current Trends of Vocabulary Teaching and Learning Strategies for EFL Settings. Journal of Feng Chia University, 7, 187-224.

Cohen, A. D. (1990). Language learning. Insights for learners, teachers and researcher. Boston, Mass.: Heinle and Heinle Publishers. Collins Co build Dictionary. Great Britain: Richard Clay Ltd.

Cohen, A. D. (2000). Strategies in learning and using a second language. Beijing: Foreign Language Teaching and Research Press.

Ellis, R. (1997). Second language acquisition. Oxford: Oxford University Press. (Online).

Ellis, N. C. (1994). Vocabulary acquisition: Psychological perspectives and pedagogical implications. The Language Teacher, 19(2), 12-16.

Gruber, G. (1986). Essential guide to test taking for kids, grades 6, 7, 8, \& 9. Collins: New York City.

Nemati, A. B. (2008). Vocabulary retention technique through an organized learning scheme. Indian Linguistics, 69(1-4), 289-296.

O'malley, J. M., \& Chamot, A. U. (1990). Learning strategies in second language acquisition. Cambridge: Cambridge University Press.

Pitman, W. (2003). Building Vocabulary through Prefixes, Roots and Suffixes. The Internet TESL Journal, IX (7). http://iteslj.org/

Schmitt, N. (2000). Vocabulary in language teaching. Cambridge: Cambridge University Press. 